UDC $519.85+534.1$

\author{
V.P. Legeza*, O.M. Neshchadym, T.M. Zabolotnia \\ Igor Sikorsky Kyiv Polytechnic Institute, Kyiv, Ukraine \\ *corresponding author: viktor.legeza@gmail.com
}

\title{
MODELLING THE PROCESS OF DAMPING LONGITUDINAL LOADS IN TRANSPORT SYSTEMS USING ROLLER IMPACT ABSORBERS
}

\begin{abstract}
Background. In this work, for a defect-free transportation of large-sized structures by rail, a new damping system for longitudinal dynamic loads is proposed. Its operation is based on the use of roller impact absorbers. The relevance of this work is explained by significant volumes of damaged and destroyed structures at the transportation stage.

Objective. The goal is to develop a mathematical model of the process of damping longitudinal loads in a transport system with roller impact absorbers. The paper considers an extreme version of the dynamic loading of a transport system in the process of its collision with a railway stopper car.

Methods. Based on the Appel formalism for non-holonomic systems, kinematic and dynamic equations of motion of the transport system are formulated that describe the process of damping longitudinal loads. The obtained equations were numerically integrated using the developed program. Using it, a series of numerical experiments was carried out with varying parameters of the transport system.

Results. The main regulatory parameters of roller impact absorbers, which significantly affect the quality of their functioning, are determined. The laws of their influence on the dynamic state of transported goods are established. A quantitative assessment of the effectiveness of the use of roller impact absorbers to reduce dynamic loads on transported structures.

Conclusions. It has been established that dynamic loads on transported goods can be reduced by more than 14 times compared with the existing traditional schemes and methods of securing structures. The main conclusion is made: in order to significantly reduce the level of longitudinal transport loads on the transported goods, their fixation relative to the wagons should be carried out in a "movable-adjustable" way (in contrast to the traditional "hard" method).

Keywords: process of damping; transport system; turnstile; roller impact absorber; coupler of rail cars; longitudinal loads.
\end{abstract}

\section{Introduction}

In the modern practice of railway transportation of various cargoes, significant amounts constitute building structures. Rail transport becomes especially indispensable in the case when it comes to transporting large-sized reinforced concrete structures over long distances. For example, such transportation on a large scale must be realized in the process of building power plants, industrial enterprises, railway and automobile bridges, etc. [1-7].

Since the nomenclature of reinforced concrete structures is quite wide, their transportation is carried out using universal railway cars (open wagons and platforms). These railway cars are not equipped with mobile support beams. There are no requirements for such wagons that would limit the conditions for their operation during the transportation of these structures. At the same time, their dimensions, mass characteristics, and conditions of attachment (support) differ significantly from those conditions that characterize the transportation of other types of usual cargoes.
As a rule, reinforced concrete structures with respect to universal railway cars are fixed in accordance with the traditional method - "rigidly", without the possibility of moving them relative to the floor of the cars [3-5, 7-11]. At the same time, reinforced concrete structures, which are specially designed to perform their basic functions as elements of a future building, are not designed for specific dynamic loads that arise in terms of their transportation by rail $[1-4,6,7,12-17]$.

The consequence of this situation is the large amount of damage to reinforced concrete structures of many types at the transport stage, which causes great damage to the national economy.

Each year during transportation by rail about $7 \%$ of large-sized reinforced concrete structures are destroyed or suffer significant damage, which require major repairs even before they are installed on the future building [1-3, 12-14].

The main reason for the destructive dynamic loads on building structures during their transportation by rail are longitudinal inertial forces [1-14], 
which for them are not design-calculated. Therefore, reducing the level of these inertial forces to the normative is an urgent scientific and technical challenge $[1-9,11-14]$, which is of great national economic importance.

To solve the problem of preserving the quality of building structures at the stage of transportation by rail, different methods are used to fasten them on special shock-absorbing bearing supports - turnstiles, which serve as an intermediate link between the transported cargo (building structure) and its bearing rail cars $[1-3,13-16]$. Among them, the most promising are the turnstiles with roller impact absorbers, the dynamic behavior of which is considered in this article.

When using these impact absorbers, an important feature is the factor of reliable return of the transported cargo to its original position without accumulating the relative movement of cargo on the wagons. After the impact, a significant part of the initial kinetic energy of the cargo is absorbed by the dampers installed on the turnstile supports. Since the damping system is dynamically stable, it gives it the opportunity to self-adjust and be ready for the next impact.

This development is a continuation of previous studies of the dynamic behavior of damping systems equipped with rolling-damping devices of various designs [2, 15-17].

The construction of a mathematical model of the dynamics of the transport system was carried out on the basis of the assumption of non-slip cylindrical rolling elements of roller absorbers relative to the cylindrical surfaces of the upper support frames of the turnstiles. The cargo is fixed on these turnstiles hingedly. In addition, the mathematical model takes into account the mutual influence of the movements of a large-sized structure and its supporting platforms. This influence is carried out through kinematic ties that realized roller impact absorbers and elastic-friction ties in rail cars automatic coupling.

\section{Problem statement}

Unlike the main set of studies in the field of transportation of bulky cargos by rail, this work is aimed at studying specific dynamic loads acting on particularly fragile and destructible loads that are not adapted and are not structurally designed for specific longitudinal effects.

Thus, the aim of this work is to quantify the effectiveness of the functioning of roller impact absorbers in the transportation of heavy and bulky cargos by rail.

\section{Assumptions that have been taken into account when setting the problem}

Consider the longitudinal vibrations of the transport system "large-sized cargo with a mass $m_{5}-$ turnstiles with roller impact absorbers - a coupler from two railway platforms with masses $m_{1}$ and $m_{2}$ " after an impact with a rail car-stopper with a mass $m_{6}$ (with the possibility of its post-impact joint movement) (Fig. 1).

After the impact, the coupling of the two bearing platforms and a rail car-stopper are connected by a non-releasing elastic-friction connection and then are moved together. This scheme reflects the

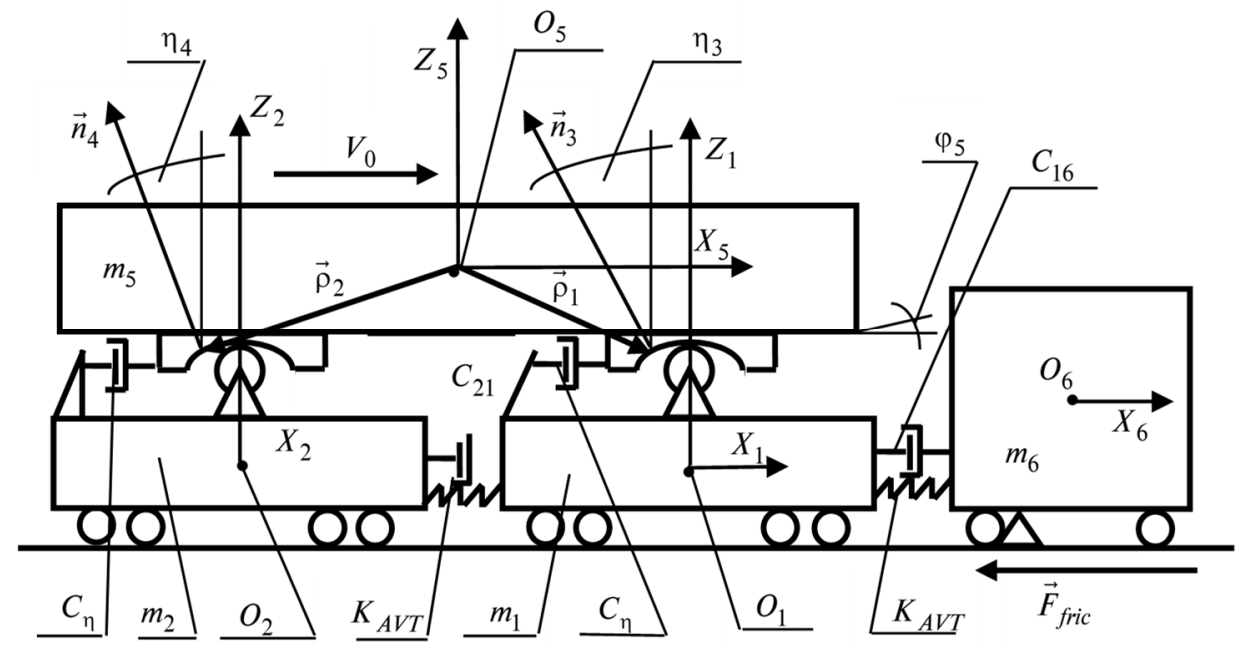

Fig. 1. Schematic diagram of the collision process of the investigated vibration protective transport system, equipped with roller shock absorbers 
real picture that occurs during the sorting and maneuvers of rolling stock and is the most disadvantageous (extreme) in terms of the level of dynamic loads and the integrity of building structures during transportation.

Structurally, each turnstile consists of two base plates and a swing frame. Each lower support plate is rigidly fixed relative to its supporting platform, and each upper support plate is hinged relative to the swing frame (Fig. 1).

The large-sized cargo (or their package) is rigidly fixed relative to each swing frame on each of the turnstiles. On the lower surface of each upper support frame, there are working cylindrical grooves with a constant radius $R$. On the upper surface of each lower support frame, two twin cylinders are hinged: rollers with a radius $r$ of each, along which the upper support frame with its curvilinear surfaces of cylindrical grooves rolls without sliding. At the same time at the ends of each of the rollers mounted spring-loaded shoes, which interact with the side edges of each upper support. This is necessary to increase the level of damping of forced oscillations of cargo on the turnstile supports. The rolling condition of the rollers without sliding along the cylindrical grooves of the upper frames is necessary from the point of view of returning the turnstiles together with the cargo to the initial position before the impact (without accumulation of relative displacements).

In Fig. 1, the impact position of the large-sized cargo itself with the rotation on the rollers at an angle $\varphi_{5}$ is not shown. However, this position can simply be represented using the image of the radius-vectors $\vec{\rho}_{1}$ and $\vec{\rho}_{2}$ drawn from the center of mass $O_{5}$ of the cargo to the new points of contact of the rollers and the corresponding working cylindrical grooves.

The construction of a mathematical model of the dynamic behavior of the transport system was carried out under the following assumptions:

- the damping system under study is a mechanical system of coupled solids;

- sliding friction is described in accordance with the Coulomb-Amonton law;

- elastic-frictional bonds between the bearing rail cars implement couplings with absorbing devices of type "Ш-I-TM" and should be modelled accordingly $[18,19]$. The elastic component of the intercarriage elastic-frictional bonds will be modelled using the following dependencies:

$$
P_{i j}=0.5 \cdot K_{A V T}\left(x_{i}-x_{j}\right),
$$

where $K_{A V T}$ is the rigidity of one absorbing device $\left(K_{A V T}=17 \mathrm{Mn} / \mathrm{m}\right)$ automatic coupler; damping in the absorbing device was taken into account for the well-known model [18]: dissipative resistance is proportional to the relative speed of the respective cars with a damping coefficient (viscous resistance) $C_{i j}=0.26 \mathrm{Mn} \cdot \mathrm{s} / \mathrm{m}$; as a result, the deformationforce characteristic of the couplings, taking into account the damping of their absorbing devices, is modeled according to the following formula:

$$
Q_{i j}=0.5 \cdot K_{A V T}\left(x_{i}-x_{j}\right)+C_{i j}\left(\dot{x}_{i}-\dot{x}_{j}\right)
$$

- the upper support frames of the turnstiles move progressively and their masses are related to the mass of the load; the masses of the lower support frames rigidly connected to the crews of the coupling - to the masses of the respective platforms;

- railway track is absolutely rigid, straight and placed on a horizontal surface;

- the vertical dynamics of carrying wagons (oscillations on springs) is not taken into account;

- rolling friction when moving rail cars with masses $m_{1}$ and $m_{2}$ on a railway track and rollers when rolling on cylindrical grooves of the upper support frames is not taken into account;

- friction in the cylindrical joints of the rollers is not taken into account;

- small angles $\varphi_{5}$ of rotation of a large-sized cargo are considered relative to its center of mass $\mathrm{O}_{5}$ (which is the case in practice) (Fig. 1).

On the basis of research $[1,2,13-16]$, the model of a rail car-stopper was taken as the calculation in the form of a separate rail car with an increased mass $m_{6}=146.7$ tonne and a sliding friction coefficient $\mu=0.15$. It was shown $[1,2,13$, 14] that such a simulation scheme of a rail car-stopper gives results that are quite close to the experimental ones.

\section{Definition of geometric, kinematic and dynamic equations of motion of the transport damping system}

The construction of the differential equations of motion of the damping system will be carried out using the theoretical-methodological approach developed earlier in publications [2, 15-17]. This approach is based on Appell's formalism for nonholonomic systems [20, 21]. 
In further transformations, we need some geometrical and kinematic relations. We formulate them below.

First, we introduce a coordinate system as shown in Fig. 1. Let us write expressions for radius vectors that connect the center of mass (CM) of a large cargo with points of tangency of the rollers and cylindrical grooves (Fig. 1):

$$
\begin{gathered}
\vec{\rho}_{1}=\left[l+q_{1}-\left(h+z_{1}\right) \varphi_{5} ; 0 ;-\left(h+z_{1}+\left(l+q_{1}\right) \varphi_{5}\right)\right], \\
\vec{\rho}_{2}=-\left[l-q_{2}+\left(h+z_{2}\right) \varphi_{5} ; 0 ; h+z_{2}-\left(l-q_{2}\right) \varphi_{5}\right],
\end{gathered}
$$

where

$$
q_{1}=\bar{R} \sin \left(\eta_{3}\right) ; q_{2}=\bar{R} \sin \left(\eta_{4}\right) ;
$$

$z_{1}=\bar{R}\left(1-\cos \left(\eta_{3}\right)\right) ; z_{2}=\bar{R}\left(1-\cos \left(\eta_{4}\right)\right) ; h-$ half the height of the load; $l-$ half the length of the load; $\bar{R}=R-r$.

Now we write down two vector kinematic relations reflecting the non-slip conditions between the rollers and the cylindrical support surfaces:

$$
\begin{aligned}
& \vec{V}_{5}+\dot{\varphi}_{5} \vec{j} \times \vec{\rho}_{1}=\dot{x}_{1} \vec{i}+\dot{\varphi}_{3} \vec{j} \times r \vec{r}_{3}, \\
& \vec{V}_{5}+\dot{\varphi}_{5} \vec{j} \times \vec{\rho}_{2}=\dot{x}_{2} \vec{i}+\dot{\varphi}_{4} \vec{j} \times r \vec{n}_{4},
\end{aligned}
$$

where

$\vec{n}_{3}=\left[\sin \left(\eta_{3}\right) ; 0 ; \cos \left(\eta_{3}\right)\right], \quad \vec{n}_{4}=\left[\sin \left(\eta_{4}\right) ; 0 ; \cos \left(\eta_{4}\right)\right]$ are external unit normals at the points of contact of the corresponding grooves; $\eta_{3}, \eta_{4}$ are the angles of deviation of the corresponding unit normals from the verticals $O_{1} Z_{1}$ and $O_{2} Z_{2}$.

We rewrite the vector relations (4), (5) in scalar form using (2), (3):

$$
\begin{gathered}
\dot{x}_{5}-\dot{\varphi}_{5}\left[h+z_{1}+\left(l+q_{1}\right) \varphi_{5}\right]=\dot{x}_{1}-\bar{R} \dot{\eta}_{3} \cos \left(\eta_{3}\right) ; \\
\dot{z}_{5}-\dot{\varphi}_{5}\left[l+q_{1}-\left(h+z_{1}\right) \varphi_{5}\right]=\bar{R} \dot{\eta}_{3} \sin \left(\eta_{3}\right) ; \\
\dot{x}_{5}-\dot{\varphi}_{5}\left[h+z_{2}-\left(l-q_{2}\right) \varphi_{5}\right]=\dot{x}_{2}-\bar{R} \dot{\eta}_{4} \cos \left(\eta_{4}\right) ; \\
\dot{z}_{5}+\dot{\varphi}_{5}\left[l-q_{2}+\left(h+z_{2}\right) \varphi_{5}\right]=\bar{R} \dot{\eta}_{4} \sin \left(\eta_{4}\right) .
\end{gathered}
$$

Let us proceed to the definition of the dynamic equations of motion of the system. Taking into account the specificity of connections in the system, for this we use the Appell's formalism [20, 21] with the construction of the corresponding acceleration function.

We write the expression for Appell's acceleration function $[20,21]$, provided that the masses $m_{3}, m_{4}$ of the rollers are infinitesimal $m_{k} / m_{1} \rightarrow 0, m_{k} / m_{2} \rightarrow 0, m_{k} / m_{5} \rightarrow 0, k=3,4$

compared with the masses of the cargo $m_{5}$ and the carrying wagons $m_{1}, m_{2}$ :

$$
\begin{gathered}
S=\frac{m_{1} \ddot{x}_{1}^{2}}{2}+\frac{m_{2} \ddot{x}_{2}^{2}}{2}+\frac{m_{5}\left(\ddot{x}_{5}^{2}+\ddot{z}_{5}^{2}\right)}{2} \\
+\frac{J_{5} \ddot{\varphi}_{5}^{2}}{2}+\frac{m_{6} \ddot{x}_{6}^{2}}{2} .
\end{gathered}
$$

For the damping system under study, we introduce four independent generalized coordinates $x_{1}, x_{2}, \eta_{3}, x_{6}$ that correspond to the number of its degrees of freedom. Let us free ourselves from the dependent velocities $\dot{x}_{5}, \dot{z}_{5}, \dot{\varphi}_{5}$ and $\dot{\eta}_{4}$, using the kinematic relations (6)-(9). As a result, we get:

$$
\dot{\eta}_{4}=\frac{F_{3} \dot{\eta}_{3}+\left(2 l+q_{1}-q_{2}\right)\left(\dot{x}_{1}-\dot{x}_{2}\right)}{Z N}
$$

where

$$
\begin{gathered}
F_{3}=\bar{R}\left[\left(z_{2}-z_{1}-2 l \varphi_{5}\right) \sin \left(\eta_{3}\right)\right. \\
\left.\quad-\left(2 l+q_{1}-q_{2}\right) \cos \left(\eta_{3}\right)\right] \\
Z N=\bar{R}\left[\left(z_{2}-z_{1}-2 l \varphi_{5}\right) \sin \left(\eta_{4}\right)\right. \\
\left.\quad-\left(2 l+q_{1}-q_{2}\right) \cos \left(\eta_{4}\right)\right] .
\end{gathered}
$$

The expression for $\ddot{\eta}_{4}$ is defined using (11) in the form:

$$
\ddot{\eta}_{4}=f_{\eta} \ddot{\eta}_{3}+f_{x}\left(\ddot{x}_{1}-\ddot{x}_{2}\right)+f_{s v},
$$

where

$$
\begin{gathered}
T C H=F_{3} \dot{\eta}_{3}+\left(2 l+q_{1}-q_{2}\right)\left(\dot{x}_{1}-\dot{x}_{2}\right) ; \\
f_{\eta}=\frac{F_{3}}{Z N} ; f_{x}=\frac{2 l+q_{1}-q_{2}}{Z N} ; \\
f_{s v}=\frac{Q_{1}}{Z N}-\frac{D Z N \cdot T C H}{Z N^{2}} ; \\
Q_{1}=\left[\dot{\eta}_{3} \cdot D F_{3}+\left(\dot{q}_{1}-\dot{q}_{2}\right)\left(\dot{x}_{1}-\dot{x}_{2}\right)\right] \cdot Z N ; \\
D F_{3}=\bar{R}\left[\left(\dot{z}_{2}-\dot{z}_{1}-2 l \dot{\varphi}_{5}\right) \sin \left(\eta_{3}\right)-\left(\dot{q}_{1}-\dot{q}_{2}\right) \cos \left(\eta_{3}\right)\right. \\
\left.+\left(z_{2}-z_{1}-2 l \varphi_{5}\right) \cos \left(\eta_{3}\right) \dot{\eta}_{3}+\left(2 l+q_{1}-q_{2}\right) \sin \left(\eta_{3}\right) \dot{\eta}_{3}\right] ; \\
D Z N=\bar{R}\left[\left(\dot{z}_{2}-\dot{z}_{1}-2 l \dot{\varphi}_{5}\right) \sin \left(\eta_{4}\right)\right. \\
-\left(\dot{q}_{1}-\dot{q}_{2}\right) \cos \left(\eta_{4}\right)+\left(z_{2}-z_{1}-2 l \varphi_{5}\right) \cos \left(\eta_{4}\right) \dot{\eta}_{4} \\
\left.+\left(2 l+q_{1}-q_{2}\right) \sin \left(\eta_{4}\right) \dot{\eta}_{4}\right] .
\end{gathered}
$$

Next, we define an expression for $\dot{\varphi}_{5}$ : 


$$
\dot{\varphi}_{5}=\frac{\bar{R}\left(\dot{\eta}_{4} \sin \left(\eta_{4}\right)-\dot{\eta}_{3} \sin \left(\eta_{3}\right)\right)}{2 l+q_{1}-q_{2}} .
$$

Using expressions (12) and (13), we write the equations for $\ddot{\varphi}_{5}$ :

$$
\ddot{\varphi}_{5}=\varphi_{\eta} \cdot \ddot{\eta}_{3}+\varphi_{x} \cdot\left(\ddot{x}_{1}-\ddot{x}_{2}\right)+\varphi_{s v},
$$

where

$$
\begin{aligned}
\varphi_{\eta}=\bar{R} & \frac{f_{\eta} \sin \left(\eta_{4}\right)-\sin \left(\eta_{3}\right)}{2 l+q_{1}-q_{2}} ; \varphi_{x}=\bar{R} \frac{f_{x} \sin \left(\eta_{4}\right)}{2 l+q_{1}-q_{2}} ; \\
\varphi_{s v} & =\bar{R}\left[\frac{f_{s v} \cdot \sin \left(\eta_{4}\right)+\dot{\eta}_{4}^{2} \cos \left(\eta_{4}\right)-\dot{\eta}_{3}^{2} \cos \left(\eta_{3}\right)}{2 l+q_{1}-q_{2}}\right. \\
& \left.-\frac{\left(\dot{q}_{1}-\dot{q}_{2}\right)\left(\dot{\eta}_{4} \sin \left(\eta_{4}\right)-\dot{\eta}_{3} \sin \left(\eta_{3}\right)\right)}{\left(2 l+q_{1}-q_{2}\right)^{2}}\right] .
\end{aligned}
$$

Now we define the expressions for $\ddot{x}_{5}$ and $\ddot{z}_{5}$ through the accelerations $\ddot{\eta}_{3}, \ddot{x}_{1}, \ddot{x}_{2}$ of independent generalized coordinates $\eta_{3}, x_{1}, x_{2}$, which are included in the Appell's acceleration function (10). Using relations (12) and (14), we write the equation for $\ddot{x}_{5}$ :

$$
\begin{gathered}
\ddot{x}_{5}=K X 5_{\eta} \cdot \ddot{\eta}_{3}+K X 5_{X_{1}} \cdot \ddot{x}_{1} \\
+K X 5_{X_{2}} \cdot \ddot{x}_{2}+K X 5_{S V},
\end{gathered}
$$

where

$$
\begin{gathered}
K X 5_{\eta}=H Z_{\varphi} \cdot \varphi_{\eta}-\bar{R} \cos \left(\eta_{3}\right) ; \\
K X 5_{X_{1}}=H Z_{\varphi} \cdot \varphi_{x}+1 ; K X 5_{X_{2}}=-H Z_{\varphi} \cdot \varphi_{x} ; \\
K X 5_{S V}=H Z_{\varphi} \cdot \varphi_{s v}+\bar{R} \dot{\eta}_{3}^{2} \sin \left(\eta_{3}\right) \\
+\dot{\varphi}_{5}\left[\dot{z}_{1}+\dot{q}_{1} \varphi_{5}+\left(l+q_{1}\right) \dot{\varphi}_{5}\right] \\
H Z_{\varphi}=h+z_{1}+\left(l+q_{1}\right) \varphi_{5} .
\end{gathered}
$$

Similarly, we obtain the expression for $\ddot{z}_{5}$ :

$$
\ddot{z}_{5}=K Z 5_{\eta} \cdot \ddot{\eta}_{3}+K Z 5_{X} \cdot\left(\ddot{x}_{1}-\ddot{x}_{2}\right)+K Z 5_{S V},
$$

where

$$
\begin{gathered}
K Z 5_{\eta}=L Q_{\varphi} \cdot \varphi_{\eta}+\bar{R} \cdot \sin \left(\eta_{3}\right) ; \\
K Z 5_{X}=L Q_{\varphi} \cdot \varphi_{x} ; \quad L Q_{\varphi}=l+q_{1}-\left(h+z_{1}\right) \varphi_{5} ; \\
K Z 5_{S V}=L Q_{\varphi} \cdot \varphi_{S v}+\bar{R} \dot{\eta}_{3}^{2} \cos \left(\eta_{3}\right) \\
+\dot{\varphi}_{5}\left[\dot{q}_{1}-\dot{z}_{1} \varphi_{5}-\left(h+z_{1}\right) \dot{\varphi}_{5}\right] .
\end{gathered}
$$

After substituting expressions (14)-(16) into the acceleration function (10), we obtain a new Appell function $S^{*}$, in which we retain only those terms that contain the second derivatives of independent generalized coordinates (that is, accelerations). The new Appell acceleration function in independent generalized coordinates is:

$$
\begin{aligned}
S^{*} & =A_{X_{1}} \ddot{x}_{1}^{2}+A_{X_{2}} \ddot{x}_{2}^{2}+A_{\eta} \ddot{\eta}_{3}^{2}+A_{X_{12}} \ddot{x}_{1} \ddot{x}_{2}+A_{X_{1} \eta} \ddot{x}_{1} \ddot{\eta}_{3} \\
& +A_{X_{2} \eta} \ddot{x}_{2} \ddot{\eta}_{3}+B_{X_{1}} \ddot{x}_{1}+B_{X_{2}} \ddot{x}_{2}+B_{\eta} \ddot{\eta}_{3}+\frac{m_{6}}{2} \ddot{x}_{6}^{2},
\end{aligned}
$$

where

$$
\begin{gathered}
A_{X_{1}}=\frac{m_{1}}{2}+\frac{J_{5}}{2}\left(\varphi_{x}\right)^{2}+\frac{m_{5}}{2}\left[\left(K X 5_{X_{1}}\right)^{2}+\left(K Z 5_{X}\right)^{2}\right] ; \\
A_{X_{2}}=\frac{m_{2}}{2}+\frac{J_{5}}{2}\left(\varphi_{x}\right)^{2}+\frac{m_{5}}{2}\left[\left(K X 5_{X_{2}}\right)^{2}+\left(K Z 5_{X}\right)^{2}\right] ; \\
A_{\eta}=\frac{J_{5}}{2}\left(\varphi_{\eta}\right)^{2}+\frac{m_{5}}{2}\left[\left(K X 5_{\eta}\right)^{2}+\left(K Z 5_{\eta}\right)^{2}\right] ; \\
A_{X_{12}}=m_{5} \cdot\left[K X 5_{X_{1}} \cdot K X 5_{X_{2}}-\left(K Z 5_{X}\right)^{2}\right]-J_{5}\left(\varphi_{x}\right)^{2} ; \\
A_{X_{1} \eta}=J_{5} \varphi_{x} \varphi_{\eta} \\
+m_{5}\left(K X 5_{\eta} \cdot K X 5_{X_{1}}+K Z 5_{\eta} \cdot K Z 5_{X}\right) ; \\
A_{X_{2} \eta}=m_{5}\left(K X 5_{\eta} \cdot K X 5_{X_{2}}-K Z 5_{\eta} \cdot K Z 5_{X}\right) \\
\quad-J_{5} \varphi_{x} \varphi_{\eta} ; \\
B_{X_{1}}=J_{5} \varphi_{x} \varphi_{s v} \\
+m_{5}\left(K X 5_{S V} \cdot K X 5_{X_{1}}+K Z 5_{S V} \cdot K Z 5_{X}\right) ; \\
B_{X_{2}}=m_{5}\left(K X 5_{S V} \cdot K X 5_{X_{2}}-K Z 5_{S V} \cdot K Z 5_{X}\right) \\
\quad-J_{5} \varphi_{x} \varphi_{s v} ; \\
B_{\eta}=m_{5}\left(K X 5_{\eta} \cdot K X 5_{S V}+K Z 5_{\eta} \cdot K Z 5_{S V}\right) \\
+J_{5} \varphi_{s v} \varphi_{\eta} .
\end{gathered}
$$

We write the expression for the sum of the elementary works $\delta A$ on the virtual displacements of the corresponding points of the transport system in general. Here it should be noted that the work of reactions of kinematic relations is zero due to the non-slip of the rollers relative to the cylindrical grooves on the upper frames. In addition, in this study, we do not take into account the vertical component of the work of viscous resistance forces in the dampers. With that said, the expression for elementary work $\delta A$ has the following form:

$$
\delta A=-m_{5} g \cdot \delta z_{5}-F_{T P} \cdot \delta x_{6}-Q_{16} \cdot \delta\left(x_{1}-x_{6}\right)
$$




$$
\begin{gathered}
-Q_{21} \cdot \delta\left(x_{2}-x_{1}\right)-C_{\eta} \cdot\left(\dot{x}_{5}-\dot{x}_{1}\right) \cdot\left(\delta x_{5}-\delta x_{1}\right) \\
-C_{\eta} \cdot\left(\dot{x}_{5}-\dot{x}_{2}\right) \cdot\left(\delta x_{5}-\delta x_{2}\right),
\end{gathered}
$$

where $F_{T P}=m_{6} g \mu \cdot \operatorname{sign}\left(\dot{x}_{6}\right) ; Q_{i j}$ model for the formula (1).

Express elementary work $\delta A$ through the generalized forces. For this we use the kinematic relations (6)-(9) to exclude from the expression (18) dependent virtual displacements $\delta z_{5}$ and $\delta x_{5}$ through independent virtual displacements $\delta x_{1}$, $\delta x_{2}, \delta \eta_{3}, \delta x_{6}$. As a result, we obtain an expression for elementary work $\delta A$ through generalized forces the right-hand sides of Appell's equations:

$$
\begin{gathered}
\delta A=P_{X_{1}} \cdot \delta x_{1}+P_{X_{2}} \cdot \delta x_{2} \\
+P_{\eta 3} \cdot \delta \eta_{3}+P_{X_{6}} \cdot \delta x_{6} .
\end{gathered}
$$

Based on relations (18) and (19), we write the expressions for the generalized forces $P_{X_{1}}, P_{X_{2}}$, $P_{X_{6}}, P_{\eta 3}$ :

$$
\begin{gathered}
P_{X_{1}}=Q_{21}-Q_{16}-m_{5} g \cdot D_{X_{1}} \\
-C_{\eta}\left(2 \dot{x}_{5}-\dot{x}_{1}-\dot{x}_{2}\right) E_{X_{1}}+C_{\eta}\left(\dot{x}_{5}-\dot{x}_{1}\right) ; \\
P_{X_{2}}=C_{\eta}\left(\dot{x}_{5}-\dot{x}_{2}\right)-C_{\eta}\left(2 \dot{x}_{5}-\dot{x}_{1}-\dot{x}_{2}\right) E_{X_{2}} \\
-m_{5} g D_{X_{2}}-Q_{21} ; \\
P_{X_{6}}=Q_{16}-F_{T P} ; \\
P_{\eta 3}=-\left(m_{5} g \cdot D_{\eta 3}+C_{\eta}\left(2 \dot{x}_{5}-\dot{x}_{1}-\dot{x}_{2}\right) E_{\eta 3}\right),
\end{gathered}
$$

where

$$
\begin{gathered}
D_{\eta 3}=L Q_{\varphi} \cdot \frac{\bar{R}}{2 l+q_{1}-q_{2}} \cdot\left(\frac{F_{3} \sin \left(\eta_{4}\right)}{Z N}-\sin \left(\eta_{3}\right)\right) \\
+\bar{R} \sin \left(\eta_{3}\right) ; \\
D_{X_{1}}=L Q_{\varphi} \cdot \frac{\bar{R} \sin \left(\eta_{4}\right)}{Z N} ; D_{X_{2}}=-D_{X_{1}} ; \\
E_{X_{1}}=H Z_{\varphi} \cdot \frac{\bar{R} \sin \left(\eta_{4}\right)}{Z N}+1 ; E_{X_{2}}=1-E_{X_{1}} ; \\
E_{\eta 3}=H Z_{\varphi} \cdot \frac{\bar{R}}{2 l+q_{1}-q_{2}} \cdot\left(\frac{F_{3} \sin \left(\eta_{4}\right)}{Z N}-\sin \left(\eta_{3}\right)\right) \\
-\bar{R} \cos \left(\eta_{3}\right) .
\end{gathered}
$$
view:

Let us write the Appell's equations in a general

$$
\frac{\partial S^{*}}{\partial \ddot{x}_{1}}=P_{X_{1}} ; \frac{\partial S^{*}}{\partial \ddot{x}_{2}}=P_{X_{2}} ; \frac{\partial S^{*}}{\partial \ddot{x}_{6}}=P_{X_{6}} ; \frac{\partial S^{*}}{\partial \ddot{\eta}_{3}}=P_{\eta 3} .
$$

Performing the differentiation in accordance with (24) using relations (17), (19)-(23) after some transformations, we obtain the nonlinear differential equations of motion of the transport damping system:

$$
\begin{gathered}
2 A_{X_{1}} \cdot \ddot{x}_{1}+A_{X_{12}} \cdot \ddot{x}_{2}+A_{X_{1} \eta} \cdot \ddot{\eta}_{3}=P_{X_{1}}-B_{X_{1}}, \\
A_{X_{12}} \cdot \ddot{x}_{1}+2 A_{X_{2}} \cdot \ddot{x}_{2}+A_{X_{2} \eta} \cdot \ddot{\eta}_{3}=P_{X_{2}}-B_{X_{2}}, \\
A_{X_{1} \eta} \cdot \ddot{x}_{1}+A_{X_{2} \eta} \cdot \ddot{x}_{2}+2 A_{\eta} \cdot \ddot{\eta}_{3}=P_{\eta 3}-B_{\eta}, \\
m_{6} \ddot{x}_{6}=P_{X_{6}} .
\end{gathered}
$$

To determine the conditions for non-slipping of the rollers relative to both cylindrical surfaces of the impact absorbers, we write the equations of dynamic equilibrium using the general theorems of the dynamics of a system of connected bodies with bond reactions $\vec{R}_{1}=\left[R_{1 x} ; 0 ; R_{1 z}\right]$ and $\vec{R}_{2}=\left[R_{2 x} ; 0 ; R_{2 z}\right]$.

These equations have the following form (here we again neglect the vertical components of the viscous resistance $C_{\eta}$ of the dampers):

$$
\begin{gathered}
m_{5} \ddot{x}_{5}=R_{1 x}+R_{2 x}-C_{\eta}\left(2 \dot{x}_{5}-\dot{x}_{1}-\dot{x}_{2}\right) ; \\
m_{5} \ddot{z}_{5}=R_{1 z}+R_{2 z}-m_{5} g ; \\
m_{1} \ddot{x}_{1}=Q_{21}-Q_{16}-R_{1 x}+C_{\eta}\left(\dot{x}_{5}-\dot{x}_{1}\right) ; \\
m_{2} \ddot{x}_{2}=-Q_{21}-R_{2 x}+C_{\eta}\left(\dot{x}_{5}-\dot{x}_{1}\right) ; \\
J_{5} \ddot{\varphi}_{5}=-L Q_{\varphi} \cdot R_{1 z}-\left(R_{1 x}-C_{\eta}\left(\dot{x}_{5}-\dot{x}_{1}\right)\right) H Z_{\varphi} \\
+R_{2 z} \cdot L Q 2_{\varphi}-\left(R_{2 x}-C_{\eta}\left(\dot{x}_{5}-\dot{x}_{2}\right)\right) H Z 2_{\varphi},
\end{gathered}
$$

where

$$
\begin{aligned}
& L Q 2_{\varphi}=l-q_{2}+\left(h+z_{2}\right) \varphi_{5} ; \\
& H Z 2_{\varphi}=h+z_{2}-\left(l-q_{2}\right) \varphi_{5} .
\end{aligned}
$$

We define the horizontal components $R_{1 x}, R_{2 x}$ of the reactions of bonds from the relations (29), (31), (32):

$$
\begin{gathered}
R_{1 x}=Q_{21}-Q_{16}-m_{1} \ddot{x}_{1}+C_{\eta}\left(\dot{x}_{5}-\dot{x}_{1}\right) ; \\
R_{2 x}=C_{\eta}\left(\dot{x}_{5}-\dot{x}_{2}\right)-m_{2} \ddot{x}_{2}-Q_{21} .
\end{gathered}
$$

Further, from the relations (30) and (33), we find the relations that determine the vertical components $R_{1 z}, R_{2 z}$ of the coupling reactions: 


$$
\begin{gathered}
R_{1 z}=\frac{\left(R_{1 x}-C_{\eta}\left(\dot{x}_{5}-\dot{x}_{1}\right)\right) H Z_{\varphi}-\left(R_{2 x}-C_{\eta}\left(\dot{x}_{5}-\dot{x}_{2}\right)\right) H Z 2_{\varphi}}{L Q_{\varphi}+L Q 2_{\varphi}} \\
+\frac{J_{5} \ddot{\varphi}_{5}+m_{5}\left(\ddot{z}_{5}+g\right) \cdot L Q_{\varphi}}{L Q_{\varphi}+L Q 2_{\varphi}} \\
R_{2 z}=m_{5}\left(\ddot{z}_{5}+g\right)-R_{1 z}
\end{gathered}
$$

Determine the normal $R_{1 N}, R_{2 N}$ and tangent $R_{1 T}, R_{2 T}$ components of the reactions of kinematic relations for each roller impact absorber:

Determine the normal $R_{1 N}, R_{2 N}$ and tangent $R_{1 T}, R_{2 T}$ components of the reactions of kinematic relations for each roller impact absorber using the formulas (34)-(37):

$$
\begin{gathered}
R_{1 N}=\left(\vec{R}_{1} \cdot \vec{n}_{1}\right)=R_{1 x} \sin \left(\eta_{3}\right)+R_{1 z} \cos \left(\eta_{3}\right), \\
R_{2 N}=\left(\vec{R}_{2} \cdot \vec{n}_{2}\right)=R_{2 x} \sin \left(\eta_{4}\right)+R_{2 z} \cos \left(\eta_{4}\right), \\
R_{1 \mathrm{~T}}=\sqrt{\left(R_{1 x}\right)^{2}+\left(R_{1 z}\right)^{2}-\left(R_{1 N}\right)^{2}} ; \\
R_{2 \mathrm{~T}}=\sqrt{\left(R_{2 x}\right)^{2}+\left(R_{2 z}\right)^{2}-\left(R_{2 N}\right)^{2}} .
\end{gathered}
$$

The sliding conditions of the rollers relative to the cylindrical surfaces on the supports are determined from relations (38)-(41) when two such inequalities are fulfilled (the corresponding slip friction coefficients $\mu_{1}$ and $\mu_{2}$ are given here): The conditions for the non-slip of the rollers relative to the cylindrical surfaces on the supports are determined by the execution of two such inequalities (here $\mu_{1}$ and $\mu_{2}$ are the corresponding sliding friction coefficients):

$$
\begin{aligned}
& \mu_{1} \cdot R_{1 N}>R_{\mathrm{IT}} ; \\
& \mu_{2} \cdot R_{2 N}>R_{2 \mathrm{~T}} .
\end{aligned}
$$

By choosing from (42), (43) the greatest (of the two) coefficient of sliding friction that is $\mu_{0}=\max \left(\mu_{1}, \mu_{2}\right)$, it is possible to provide "pure" rolling rollers on the cylindrical surfaces of the upper frames without sliding.

\section{The results of the numerical analysis of the dy- namics of the transport damping system with roller impact absorbers}

The solution of the nonlinear system of differential equations (25)-(28) was carried out by numerical methods using the MathCAD software. The system parameters were taken as follows:

$$
\begin{gathered}
\bar{R}=2 \mathrm{~m} ; \quad \mu=0,15 ; \quad V_{0}=2 \mathrm{~m} / \mathrm{s} ; \quad L=12 \mathrm{~m} ; \\
h=1,5 \mathrm{~m} ; \quad l=6 \mathrm{~m} ; \quad m_{1} g=m_{2} g=0,25 \mathrm{Mn} ; \\
C_{i j}=0,26 \mathrm{Mn} \cdot \mathrm{s} / \mathrm{m} ; \quad C_{\eta}=30 \mathrm{Kn} \cdot \mathrm{s} / \mathrm{m} ; \quad m_{5} g=0,8 \mathrm{Mn} ; \\
m_{6} g=1,46 \mathrm{Mn} ; \quad K_{A V T}=17 \mathrm{Mn} / \mathrm{m} .
\end{gathered}
$$

The graphs (Fig. 2) reflect the processes of change in time $T$ of the velocities of all $\mathrm{CM}$ of the system.

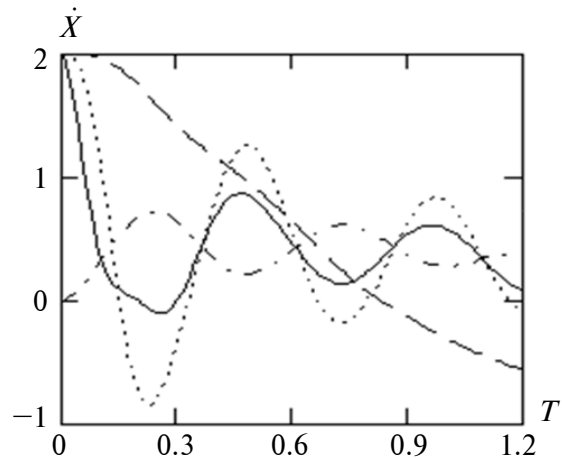

Fig. 2. Graphs of the dependences of speeds $\dot{X}_{1}, \dot{X}_{2}, \dot{X}_{5}, \dot{X}_{6}$ (m/s) on time $T(\mathrm{~s})$ of the CM of the system: $--\dot{X}_{1}, \cdots-\dot{X}_{2},---\dot{X}_{5},-\cdot--\dot{X}_{6}$

As follows from the graphs, for wagons $\left(\dot{X}_{1}, \dot{X}_{2}, \dot{X}_{6}\right)$ this change occurs very quickly, at the same time as for cargo $\left(\dot{X}_{5}\right)$ this process develops much slower. In addition, from the graphs in Fig. 2, we can conclude that the movement of the wagons practically does not affect the movement of the load, which smoothly rises along the turnstile rollers upwards. This "cut-off" of the movements of the loadcarrying platforms and the cargo explains the reason for the very small acceleration of the latter (about $3.3 \mathrm{~m} / \mathrm{s}^{2}$ ) compared with the accelerations of the rail cars (about $23 \mathrm{~m} / \mathrm{s}^{2}$ ) shown in Fig. 3 (which was to be expected).

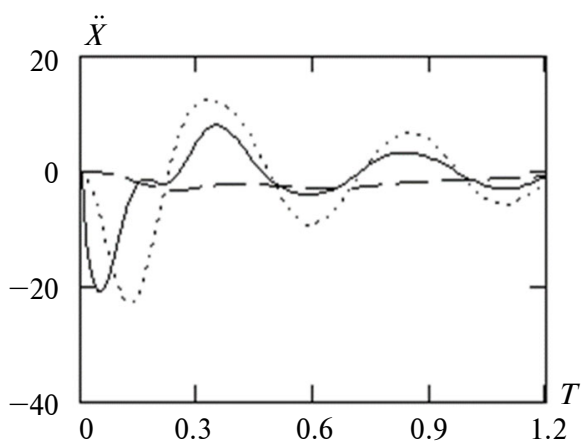

Fig. 3. Graphs of the dependences of accelerations $\ddot{X}_{1}, \ddot{X}_{2}$, $\ddot{X}_{5}\left(\mathrm{~m} / \mathrm{s}^{2}\right)$ on time $T(\mathrm{~s})$ of the CM of the system: $--\ddot{X}_{1}, \cdots-\ddot{X}_{2},---\ddot{X}_{5}$ 
For the considered design variant, the greatest acceleration CM of the cargo is seven times less than the greatest accelerations of the platforms carrying it.

The graphs (Fig. 4) show the processes of change in time $T$ of displacements $\Delta_{51}$ and $\Delta_{52}$ centers of mass of the cargo along the turnstiles' rollers relative to the coupling crews. The maximum value of the indicated displacements does not exceed $0.573 \mathrm{~m}$. The parameter $\bar{R}$ can be considered as a regulator of the longitudinal inertial forces acting on the cargo being transported. In addition, the time to reach maximum values $\Delta_{51}$ and $\Delta_{52}$ much longer than the time at which the relative interwagon displacements reach their maximum.

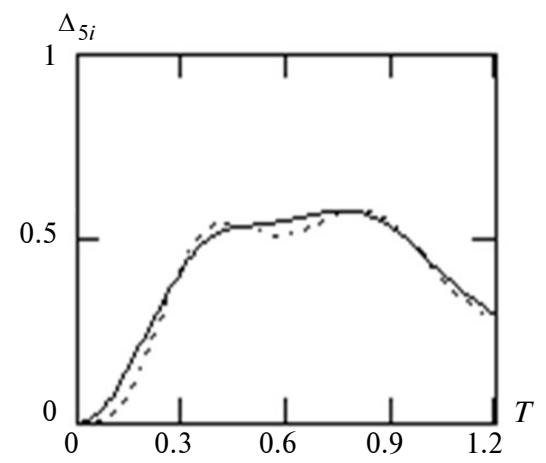

Fig. 4. Graphs of the dependence of the relative displacement $\Delta_{5 i}(\mathrm{~m})$ on time $T(\mathrm{~s})$ of the cargo onto turnstiles of the front $\Delta_{51}$ and rear $\Delta_{52}$ platforms: $--\Delta_{51}, \cdots-\Delta_{52}$

The graphs of Figs. 5 and 6 show the dependences of the longitudinal (horizontal) $R_{1 X}, R_{2 X}$ and vertical $R_{1 Z}, R_{2 Z}$ support reactions of kinematic connections at the front and rear (in the direction of impact) turnstiles in time $T$.

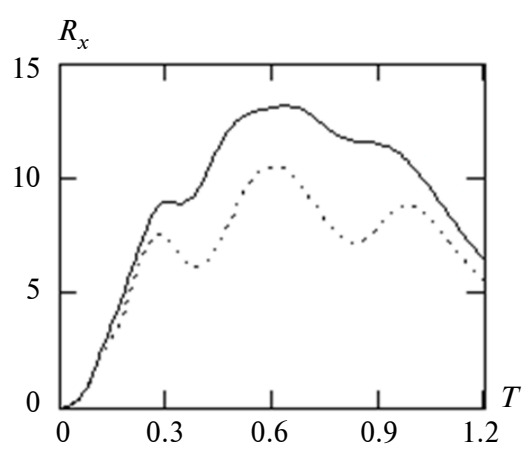

Fig. 5. Graphs of longitudinal reactions of ties $\left(\times 10^{4} n\right)$ in time $T$ (s) at the front $R_{1 X}$ and rear $R_{2 X}$ turnstiles: $--R_{1 x}$, $\cdots-R_{2 x}$
In this case, the maximum horizontal component of the coupling reaction of kinematic connections does not exceed the value of $0.131 \mathrm{Mn}$. At the same time, with the "hard" method of securing the load relative to the front crew, its acceleration would be equal to the acceleration of this crew and the horizontal component of the coupling reaction on the front leg would reach $1.84 \mathrm{Mn}$, that is, 14 times more.

This significant difference explains the high level of damage to reinforced concrete structures with the traditional "hard" method of fixing them during transportation by rail. As for the values of the vertical components of the support reactions of kinematic connections (Fig. 6) at the front $R_{1 Z}$ and rear $R_{2 Z}$ (in the direction of impact) turnstiles, they do not exceed the value $0.51 \mathrm{Mn}$. This means that the coefficient of vertical dynamics $K_{D}$ does not exceed 1.25 , which fully satisfies the requirements of the normative document [3, 12], which limits it to a value $K_{D}=1.8$.

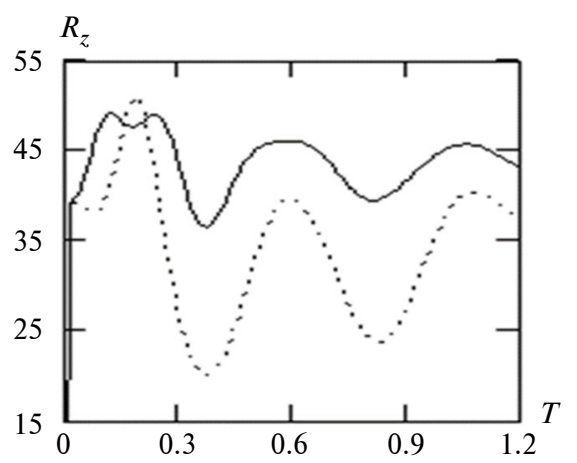

Fig. 6. Graphs of vertical reactions of ties $\left(\times 10^{4} n\right)$ in time $T(s)$ at the front $R_{1 Z}$ and rear $R_{2 Z}$ turnstiles: $--R_{1 z}$, $\cdots-R_{2 z}$

Further (Fig. 7) there are graphs of dependencies of dry friction coefficients, which ensure nonslip of the rollers at the front $\left(\mu_{35}\right)$ and rear $\left(\mu_{45}\right)$ turnstiles (in the direction of impact) against time $T$ (s).

As follows from these graphs, the value of the coefficient of dry friction does not exceed the value necessary for the realization of the "pure" rolling of rollers along the cylindrical surfaces of the upper frames of the turnstiles. Such a value of the dry friction coefficient can be obtained in the manufacture of interacting pairs "roller - cylindrical surface" from existing materials (steel, cast iron, reinforced concrete). At the same time, the specified maximum value is reached at the rear (in the course of the coupling movement) turnstile, which is "unloaded" during the longitudinal impact, and the front one is 
"loaded" in the directions of the corresponding normals.

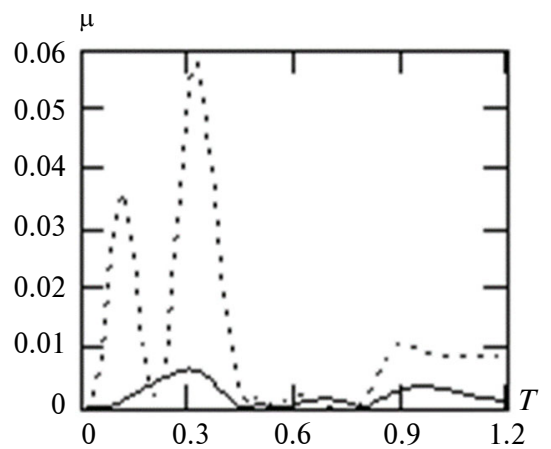

Fig. 7. Graphs of dependencies of dry friction coefficients on time $T(\mathrm{~s})$ at the front $\mu_{35}$ and at the rear $\mu_{45}$ turnstiles: $-\mu_{35}, \cdots-\mu_{45}$

Analysis of the results of numerical experiments showed that the difference between the longitudinal reactions of the turnstiles supports does not exceed the magnitude of the friction force on each of the supports. In turn, this causes the symmetry and uniform distribution of inertial forces on each of the turnstile supports. From a practical point of view, this means the absence of tensile loads in the most vulnerable for the transportation of cargoes reinforced concrete building structures.

\section{Conclusions}

It is noted that the main destructive factor in the process of transporting large-sized cargos by rail are longitudinal inertial loads. The indicated problem of reducing their level is proposed to be solved by using special devices - turnstiles with roller impact absorbers.

\section{References}

[1] S.M. Vasilyeu, "Parameters of moving turnstile-mounting devices for long cargo carrying on railway rolling stock", Ph.D. dissertation, Belarus State University of Railway Transport, Gomel, Belarus, 2011, 168 p.

[2] V.P. Legeza, Vibration Protection of Dynamic Systems with Roller Shock Absorbers. Kyiv, Ukraine: Chetverta Khvylya, 2010, 280 p.

[3] Technical Conditions for Placement and Securing of Cargo in Wagons and Containers. Moscow, Russia: Yurtrans, 2003, 544 p.

[4] Railway Goods Loading and Reinforcing Rules. Beijing, China: China Railway Press, 2015.

[5] D.Z. Wang, "Consideration on the overlength goods transportation", Railway Freight Transport, vol. 5, pp. 31-33, 2002.

[6] Y.-M. Lyu and Y.-B. Li, "Analysis and evaluation of transportation safety factors of oversize cargo", J. Transport. Eng. Inform., vol. 12, pp. 102-107, 2014.

[7] N. Andersson et al., Equipment for Rational Securing of Cargo on Railway Wagons (jvgRASLA). Swedish Agency for Innovation Systems, Sweden, VINNOVA Rep. 2004:05, 2004. 
[8] X.H. Li et al., "Analysis on factors influencing railway overweight goods transportation", in Proc. Int. Conf. Transportation (ICTR2013), Xianning, China, 4-6 December 2013, pp. 375-387.

[9] X. Li, "Factors analysis of affecting loading and reinforcing scheme of large goods in railway", World J. Eng. Technol., vol. 4, pp. 60-68, 2016, doi: 10.4236/wjet.2016.43C008

[10] P. Singh, et al., "Load securement and packaging methods to reduce risk of damage and personal injury for cargo freight in truck, container and intermodal shipments", J. Appl. Packag. Res., vol. 6, no. 1, Article 6, 2014. doi: $10.14448 /$ japr.01.0005

[11] X.-Q.Li et al., "Analysis and evaluation of factors influencing loading scheme security of exceptional dimension freight", Railway Transport and Economy, vol. 30, pp. 32-34, 2008.

[12] State Design Standards (Loads and Actions), DBN V.1.2-2:2006, 2006.

[13] S.M. Vasilyeu, "Comparative analysis of dynamic characteristics of turnstile and fastening devices of roller, skid or v-types", Science and Transport Progress. Bulletin of Dnipropetrovsk National University of Railway Transport, no. 23, pp. 16-19, 2008.

[14] S.M. Vasilyeu et al., "Cars impact simulation at dry friction in cargo suppots", Science and Transport Progress. Bulletin of Dnipropetrovsk National University of Railway Transport, no. 4, pp. 32-34, 2016. doi: 10.15802/stp2016/77990

[15] V.P. Legeza, "Kinematics and dynamics of a mechanical system on rollers that provide nonholonomic constraints", J. Math. Sci., vol. 72, no. 5, pp. 3299-3305, 1994. doi: 10.1007/BF01261684

[16] V.P. Legeza, "Application of the theory of roller shock absorbers to the vibroprotection of transport structures", Strength of Materials, vol. 38, no. 2, pp. 214-219, 2006. doi: 10.1007/s11223-006-0034-5

[17] V.P. Legeza et al., "Mathematical model of the dynamics in a one nonholonomic vibration protection system", Int. J. Intell. Syst. Applic., vol. 10, no. 10, pp. 20-26, 2018. doi: 10.5815/ijisa.2018.10.03

[18] L.N. Nikolskiy and B.G. Keglin, Shock Damper of Rolling Stock. Moscow, Russia: Mashinostroeniye, 1986, $144 \mathrm{p}$.

[19] S.V. Vershinsky et al., Dynamics of the Wagon. Moscow, Russia: Transport, 1991, 360 p.

[20] A.I. Lurie, Analytical Mechanics. Berlin, Germany: Springer-Verlag, 2002, 864 p.

[21] Yu.I. Neimark and N.A. Fufayev, Dynamics of Nonholonomic Systems. Providence: Am. Math. Soc., 2004,518 p.

В.П. Легеза, О.М. Нещадим, Т.М. Заболотня

МОДЕЛЮВАННЯ ПРОЦЕСУ ДЕМПФІРУВАННЯ ПОЗДОВЖНІХ НАВАНТАЖЕНЬ У ТРАНСПОТРНИХ СИСТЕМАХ ІЗ ВИКОРИСТАННЯМ РОЛИКОВИХ АМОРТИЗАТОРІВ

Проблематика. Для бездесектного транспортування великогабаритних конструкцій залізницею в роботі запропоновано нову систему демпфірування поздовжніх динамічних навантажень. Її функціонування ґрунтується на застосуванні роликових амортизаторів. Актуальність роботи пояснюється значними об'ємами пошкоджених і зруйнованих конструкцій на стадії транспортування.

Мета дослідження. Поставлено мету - розробити математичну модель процесу демпфірування поздовжніх навантажень у транспортній системі з роликовими амортизаторами. В роботі розглядається екстремальний варіант динамічного навантаження транспортної системи в процесі її зіткнення з вагоном-стопором.

Методика реалізації. Із залученням формалізму Аппеля для неголономних систем сформульовано кінематичні й динамічні рівняння руху транспортної системи, які описують процес демпфірування поздовжніх навантажень. Отримані рівняння чисельно проінтегровані за допомогою розробленої програми. 3 її використанням було проведено серію числових експериментів при варіюванні параметрів транспортної системи.

Результати дослідження. Визначено основні регулюючі параметри роликових амортизаторів, які суттєво впливають на якість їх функціонування. Встановлено закономірності їх впливу на динамічний стан вантажів, що перевозяться. Проведено кількісну оцінку ефективності використання роликових амортизаторів для зниження динамічних навантажень на транспортовані конструкції.

Висновки. Встановлено, що динамічні навантаження на транспортовані вантажі можна зменшити більш ніж у 14 разів порівняно $з$ існуючими традиційними способами закріплення конструкцій. Зроблено основний висновок: для того щоб суттєво знизити рівень поздовжніх транспортних навантажень на конструкції, їх фріксація відносно залізничних вагонів має здійснюватися "рухомо-регульованим" способом (на відміну від традиційного “жорсткого” способу).

Ключові слова: процес демпфірування; транспортна система; турнікет; роликовий амортизатор; зчеп залізничних вагонів; поздовжні навантаження. 
В.П. Легеза, А.М. Нещадим, Т.Н. Заболотная

\section{МОДЕЛИРОВАНИЕ ПРОЦЕССА ДЕМПФИРОВАНИЯ ПРОДОЛЬНЫХ НАГРУЗОК В ТРАНСПОРТНЫХ СИСТЕМАХ С ИСПОЛЬЗОВАНИЕМ РОЛИКОВЫХ АМОРТИЗАТОРОВ}

Проблематика. Для бездефектного транспортирования крупногабаритных конструкций по железной дороге в работе предложена новая система демпфирования продольных динамических воздействий. Ее функционирование основано на применении роликовых амортизаторов. Актуальность этой работы объясняется значительными объемами поврежденных и разрушенных конструкций на стадии транспортирования.

Цель исследования. Поставлена цель - разработать математическую модель процесса демпфирования продольных воздействий в транспортной системе с роликовыми амортизаторами. В работе рассматривается экстремальный вариант динамической нагрузки транспортной системы в процессе ее столкновения с железнодорожным вагоном-стопором.

Методика реализации. С привлечением формализма Аппеля для неголономных систем сформулированы кинематические и динамические уравнения движения транспортной системы, которые описывают процесс демпфирования продольных нагрузок. Полученные уравнения были численно проинтегрированы с помощью разработанной программы. С ее использованием была проведена серия численных экспериментов при варьровании параметров транспортной системы.

Результаты исследования. Определены основные регулирующие параметры роликовых амортизаторов, которые существенно влияют на качество их функционирования. Установлены закономерности их влияния на динамическое состояние перевозимых грузов. Проведена количественная оценка эффективности использования роликовых амортизаторов для снижения динамических нагрузок на перевозимые конструкции.

Выводы. Установлено, что динамические нагрузки на перевозимые грузы могут быть уменьшены более чем в 14 раз по сравнению с существующими традиционными способами закрепления конструкций. Сделан основной вывод: для того чтобы существенно снизить уровень продольных транспортных нагрузок на конструкции, их фиксация относительно железнодорожных вагонов должна осуществляться “подвижно-регулируемым” способом (в отличие от традиционного “жесткого” способа).

Ключевые слова: процесс демпфирования; транспортная система; турникет; роликовый амортизатор; сцеп железнодорожных вагонов; продольные нагрузки.

Рекомендована Радою

факультету прикладної математики

КПІ ім. Ігоря Сікорського
Надійшла до редакції 05 лютого 2020 року

Прийнята до публікації 05 червня 2020 року 